\title{
A novel Bacillus sp. isolated from rotten seaweed: Identification and characterization alginate lyase its produced
}

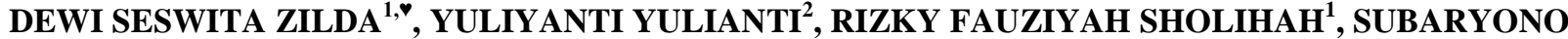 \\ SUBARYONO ${ }^{1}$, YUSRO NURI FAWZYA ${ }^{1}$, HARI EKO IRIANTO ${ }^{1}$ \\ ${ }^{1}$ Research Center for Marine and Fisheries Product Processing and Biotechnology, J1.KS Tubun Petamburan VI, 10260, Central Jakarta, Indonesia \\ Indonesia. Tel./fax.: +62-21 53650158, ”email: seswitazilda@kkp.go id \\ ${ }^{2}$ Program of Biotechnology, Universitas Teknologi Sumbawa. J1. Raya Olat Maras, Sumbawa 84371, West Nusa Tenggara, Indonesia
}

Manuscript received: 14 December 2018. Revision accepted: 28 March 2019.

\begin{abstract}
Zilda DS, Yulianti Y, Sholihah RF, Subaryono S, Fawzya YN, Irianto HE.2019. A novel Bacillus sp. isolated from rotten seaweed: identification and characterization alginate lyase its produced. Biodiversitas 20: 1166-1172. Alginate lyase has been known as potential biocatalyst not only for industrial but also medicinal application especially for the production of oligosaccharides which have distinct bioactivities. An alginate lyase, AlgT513, has been isolated from rotten seaweed bacterium strain T513 and characterized. The bacterium showed low similarity (95\%) with Bacillus tequilensis strain 10b based on 16S rDNA sequence indicating that AlgT513 may be a novel Bacillus species. The bacterium forms a clear zone on solid medium with $0.5 \%$ sodium alginate addition. The optimum temperature and $\mathrm{pH}$ were $50^{\circ} \mathrm{C}$ and 8 respectively. AlgT513 maintained stability at board $\mathrm{pHs}$ of $4-9$ and temperature of $45^{\circ} \mathrm{C}$. Metal ions $\mathrm{Mg}^{2+}, \mathrm{Ca}^{2+}$ and $\mathrm{K}^{+}$increase the activity of the enzyme while $\mathrm{Zn}^{2+}, \mathrm{Co}^{2+}$ and $\mathrm{Li}^{+}$strongly inhibit it. NaCl inhibits AlgT513 activity where most of the alginate lyases need it to reach maximum activity. AlgT513 is suggested as a serine metalloenzyme due to inhibition of ethylenediaminetetraacetic acid (EDTA) and phenylmethylsulfonyl fluoride (PMSF).
\end{abstract}

Keywords: Alginate Lyase, AlgT513, Bacillus sp., rotten seaweed

\section{INTRODUCTION}

Alginate is an acidic polysaccharide composing of monomeric units $\beta$-D-mannuronic acid (M) and $\alpha$-Lguluronic linked by 1.4 glycosidic bonds comprising $\mathrm{M}$ (M-block) or G-consecutive sequence (G-block) and $\mathrm{M} / \mathrm{G}$ random sequence (MG-block) (Vera et al. 2011). Alginate is widely applied in various industries as stabilizer (Guan et al. 2017; Rescignano et al. 2015; Zhao et al. 2014), viscosifier (Steinert et al. 2003) gelling agent (Ching et al. 2017), biomaterials (Schütz et al. 2017; Bendtsen et al. 2017) and drug delivery device (Agüero et al. 2017; Strand et al. 2017). Alginate is also used in paper and printing factory (Müller et al. 2017).

The enzyme using alginate as a substrate, Alginate lyases (also known as alginases or alginate depolymerases), catalyze the cleavage of the 1-4 glycosidic bond of alginate via the $\beta$-elimination mechanism. There are 2 classes of Alginate lyases based on the kind of alginate structure they work on, polyguluronate lyase (EC 4.2.2.1) on G blocks, polymannuronate lyase (EC 4.2.2.3) on $\mathrm{M}$ blocks, and alginate lyase degrading both $\mathrm{M}$ and $\mathrm{G}$ blocks. Alginate lyase degrading $\mathrm{G}$ or $\mathrm{M}$ block is named monofunctional and those degrading both $G$ and $M$ block named bifunctional alginate lyase. Some organisms were reported generating alginate lyase such as marine algae (Wijesekara et al. 2011), marine mollusca (Boyen et al. 1990: Shimizu et al. 2003), fungi (Perullini et al. 2010; Schaumann et al. 1995), bacteria (Chen et al. 2018; Sun et al. 2019) and viruses (Suda et al. 1999). Alginate lyases have been used to analyze the structure of alginate (Heyraud et al. 1996; Ostgaard 1993; Ostgaard 1992) protoplast seaweed, production of poly $\mathrm{G}$ and poly $\mathrm{M}$ and to treat the $\mathrm{CF}$ sufferers (Mrsny et al. 1996). Alginate lyase was also used to depolymerize alginate generating low molecular weight alginate. The degradation product of alginate lyase, oligomeric alginate had been applied as a growth promoter, germination enhancer and elongation shooter in plants (Yonemoto et al. 1993), food sources (Murata et al. 1993). In health and pharmacy field, alginate oligomer has been examined for antitumor (Fujihara et al. 1992), antiobesities (Nakazono et al. 2016) and anti-bacteria (Pritchard 2017; Oakley 2018)

Enzymes for seaweed polysaccharide degradation are mainly produced by microorganisms (Kim et al. 2012). Screening of those microorganisms from environment which rich of suitable substrate will lead to the discovery of new enzyme as well new application in biotechnology. Seaweed is a promising host for novel microorganism discovery which produces seaweed polysaccharides as revealed by Agusman et al. (2017) that seaweed have high bacteria diversity. Turbinaria, which rich of alginate was chosen for alginate lyase-producing microorganisms isolation. Decomposition process was carried out to ensure microorganisms growing on it are alginate lyase-producing ones. In this study, an alginate lyase-producing bacterium, screened from rotten Turbinaria and the enzyme its produced, AlgT513, was ammonium sulfate-precipitated and characterized. 


\section{MATERIALS AND METHODS}

\section{Screening of alginate lyase producing bacteria}

Screening of alginate lyase producing-bacteria was conducted by decomposing $100 \mathrm{~g}$ seaweed, Turbinaria, naturally in flasks covered by cotton and incubated at $37^{\circ} \mathrm{C}$ for 7 days. The rotten seaweed was blended and $1 \mathrm{~g}$ of the blended was grown in a selective medium containing $0.5 \%$ sodium alginate, $0.6 \% \mathrm{H}_{3} \mathrm{PO}_{4}, 0.3 \% \mathrm{NH}_{2} \mathrm{SO}_{4}, 0.02 \%$, and $\mathrm{MgCl}_{2}$. The culture was incubated at $37^{\circ} \mathrm{C}$ for 3 days in shaking incubator with $100 \mathrm{rpm}$ rotation. $1 \mathrm{~mL}$ of culture was spread on selective solid media with a series of dilution. Single colonies with different pattern were collected and spread on new solid media to obtain pure isolates. Iodine solution $\left(10 \mathrm{~g} \mathrm{I}_{2}\right.$ and $5 \mathrm{~g} \mathrm{KI}$ in $1000 \mathrm{~mL}$ distilled water) was poured on to the single colony and clear zone around the colony was measured. Alginolitic index was determined as the diameter of the clear zone divided by the diameter of the colony.

\section{Identification of bacterial strain}

DNA extraction kit (Guangzhou Dongsheng Biotech Co., Ltd., China) was used to extract genomic DNA of strain T513 following the manufacturers' instruction. Amplification of 16S rRNA gene was performed by PCR using the primers 27F AGAGTTTGATCCTGGCTCAG-3') and 1492R (5' GGCTACCTTGTTACGACTT-3' ) (Moreno et al. 2002) with the genome of strain T513 as a template. The PCR product was sequenced, and the homology of 16S rRNA sequence was searched using the BLAST program (Altschul et al. 1997) against the GenBank database. The phylogenetic tree was built using MEGA 7.0 software (bootstrap: 1000) (Tamura et al. 2013) with the neighborjoining method (Saitou and Nei 1987).

\section{Alginate lyase production}

Bacterium isolate T513 was refreshed from glycerol stock into $15 \mathrm{~mL}$ Luria Bertani Broth and incubated for 24 $\mathrm{h}$. The fresh culture was tricked on to plate agar containing $0.5 \%$ sodium alginate, $0.6 \% \mathrm{H}_{3} \mathrm{PO}_{4}, 0.3 \% \mathrm{NH}_{2} \mathrm{SO}_{4}, 0.02 \%$, and $0.01 \mathrm{MgCl}_{2}$ and incubated at $37^{\circ} \mathrm{C}$ The isolate of $\mathrm{T} 513$ from $24 \mathrm{~h}$-solid culture was inoculated into $50 \mathrm{~mL}$ starter media and incubated in a $150 \mathrm{rpm}$ shaker incubator at $37^{\circ} \mathrm{C}$. After $72 \mathrm{~h}, 5 \%$ starter was inoculated into $4 \times 250 \mathrm{~mL}$ production in $1 \mathrm{~L}$ flasks and incubated at the same condition with the starter culture. The culture was harvested after $72 \mathrm{~h}$ and centrifuged for 10 minutes at $10000 \mathrm{rpm} 4^{\circ} \mathrm{C}$. The purification process was carried out in 4 steps, ammonium sulfate precipitation, dialysis, ion exchange, and gel filtration. Precipitation step was conducted by addition of $70 \%$ saturation ammonium sulfate at low temperature (by putting the enzyme container on ice). After whole night incubation, the ammonium sulfate added supernatant was centrifuged at $10.000 \mathrm{rpm}$ for 30 minutes at $4^{\circ} \mathrm{C}$ and the precipitated protein was dissolved in $50 \mathrm{mM}$ phosphate buffer $\mathrm{pH}$ 7. Remained ammonium sulfate in precipitated protein was removed by dialysis using $10000 \mathrm{Da}$ co cellulose membrane with 25 $\mathrm{mM}$ phosphate buffer $\mathrm{pH} 7$ for $12 \mathrm{~h}$. The buffer for dialysis was changed every $3 \mathrm{~h}$.

\section{Alginate lyase activity}

Alginate lyase activity was determined by measuring the amount of reducing sugar as the result of sodium alginate hydrolysis using the 3,5 dinitrosalicylic acid (DNS) method (Miller 1959). The mixture of $0.9 \mathrm{~mL} 0.5 \%$ alginate lyase (in $50 \mathrm{mM}$ Tris- $\mathrm{Cl}$ buffer $\mathrm{pH}$ of 8 ) and 0.1 $\mathrm{mL}$ enzyme was incubated at $45^{\circ} \mathrm{C}$ for 30 minutes. The reaction was stopped by heating the mixture in boiled water for 10 minutes before being added by $0.5 \mathrm{~L}$ DNS reagent and heated for 10 minutes. The mixture was cooled in room temperature and the absorbance was measured at $540 \mathrm{~nm}$. One unit of alginate lyase activity was defined as the amount of enzyme that releases $1 \mu \mathrm{g}$ the reducing sugar (D glucose equivalent) per minute under assay condition.

\section{Effect of temperature and $\mathbf{p H}$}

Optimum temperature was determined by incubating substrate with the enzyme at a temperature of $30-65^{\circ} \mathrm{C}$. To obtain optimum $\mathrm{pH} 0.5 \%$ sodium alginate was dissolved in various of $\mathrm{pH}$ buffer of acetate (4-6), phosphate (6-7) and Tris-Cl (7-9). The activity was measured as described above. Both optimum temperature and $\mathrm{pH}$ were defined as $\mathrm{U} / \mathrm{mL}$. To determine thermal stability, the enzyme was incubated at an optimum temperature and $5^{\circ}$ below optimum temperature for 150 minutes. Enzyme activity was measured every 15 minutes. $\mathrm{pH}$ stability was determined by incubating enzyme in various $\mathrm{pH}$ buffer ( 49) for $12 \mathrm{~h}$ at $4^{\circ} \mathrm{C}$. The activity was defined as a relative activity with activity without treatment as $100 \%$ activity.

\section{Effect of metal ions}

Effect metal ions, $\mathrm{Ca}^{2+}, \mathrm{Co}^{2+}, \mathrm{Mn}^{2+}, \mathrm{Zn}^{2+}, \mathrm{Mg}^{2+}, \mathrm{Fe}^{2+}$, $\mathrm{Li}^{+}$, and $\mathrm{K}^{+}$, were determined by incubating the mixture of enzyme, the substrate in optimum $\mathrm{pH}$ buffer and metal ion at a final concentration of 1 and $10 \mathrm{mM}$ and the activity was measured as described above. The activity was defined as a relative activity with activity without metal ion addition as $100 \%$ activity.

\section{Effect of chemicals and detergent}

Effect of chemicals (EDTA, Mercaptoethanol, PMSF) and $0.1-1 \%$ detergent (SDS, Tween 80, Triton-100) were determined by incubating the mixture of enzyme, the substrate in optimum $\mathrm{pH}$ buffer and the compounds at final concentration mentioned above for 30 minutes at optimum temperature and $\mathrm{pH}$. The activities were measured after treatment and determined as relative activity (\%) with enzyme without treatment as $100 \%$ activity.

\section{RESULTS AND DISCUSSION}

\section{Bacterial strain}

The bacterium T513 is one of three isolates forming clear zone from 8 selected isolates (the data was not presented). Clear zone formed by T513 on solid medium with $0.5 \%$ sodium alginate as substrate was higher than those shown by other isolates (Index alginolytic $=6.8$ ) 
(Figure 1.). In the next discussion, alginate lyase produced by T513 will be mentioned as AlgT513. Identification using 16S rDNA region blasted with the database on NCBI showed that $\mathrm{T} 513$ has $95 \%$ similarities with Bacillus tequilensis strain 10b (Accession Number: NR_104919.1). The 16 rDNA sequence of T513 has been submitted to DDJB GenBank with Accession Number of LC457966. Neighbor-joining phylogenetic tree showing the relationship of T513 with members of Bacillus present in GenBank based on 16S rRNA gene was presented in Figure 2.

Some microorganisms were reported producing alginate lyase, i.e. Wenyingzhuangia fucanilytica (Pei et al. 2018), Isoptericola halotolerans CGMCC 5336 (Chen et al. 2018), Sphingomonas sp. (He et al. 2018; Park et al. 2012; Ryu and Lee 2011), Vibrio furnissii ( Zhu et al. 2018), Microbulbifer sp. ALW1 (Zhu et al. 2016; Swift et al. 2014), Flavobacterium sp. (Inoue et al. 2014; Huang et al. 2013), Vibrio sp. (Wang et al. 2013), Pseudomonas aeruginosa (Farrell and Tipton 2012), Pseudomonas alginovora (Lundqvist et al. 2012), Stenotrophommonas maltophilia (Lee et al. 2012), Saccharophagus degradans (Kim et al. 2012), Pseudomonas fluorescens (Li et al.
2011), Agarivorans sp. (Kobayashi et al. 2009), Alteromonas sp. (Iwamoto et al. 2001), Corynebacterium sp. (Matsubara et al.1998), Pseudoalteromonas elyakovii (Ma et al. 2008), Pseudomonas syringae (Preston et al. 2000), and Streptomyces sp. (Cao et al. 2007; Kim et al. 2009).

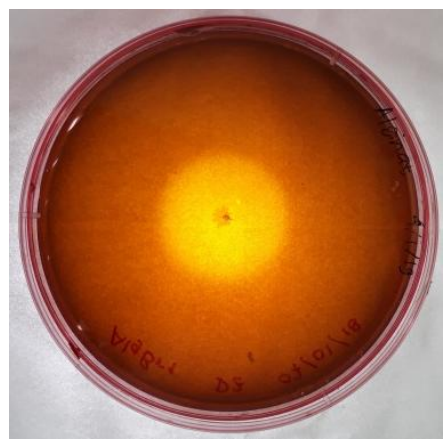

Figure 1. Clear area around T513's colony grown on plate agar containing $0.5 \%$ sodium alginate. Incubation was carried out at a temperature of $37^{\circ} \mathrm{C}$ for 2 days.

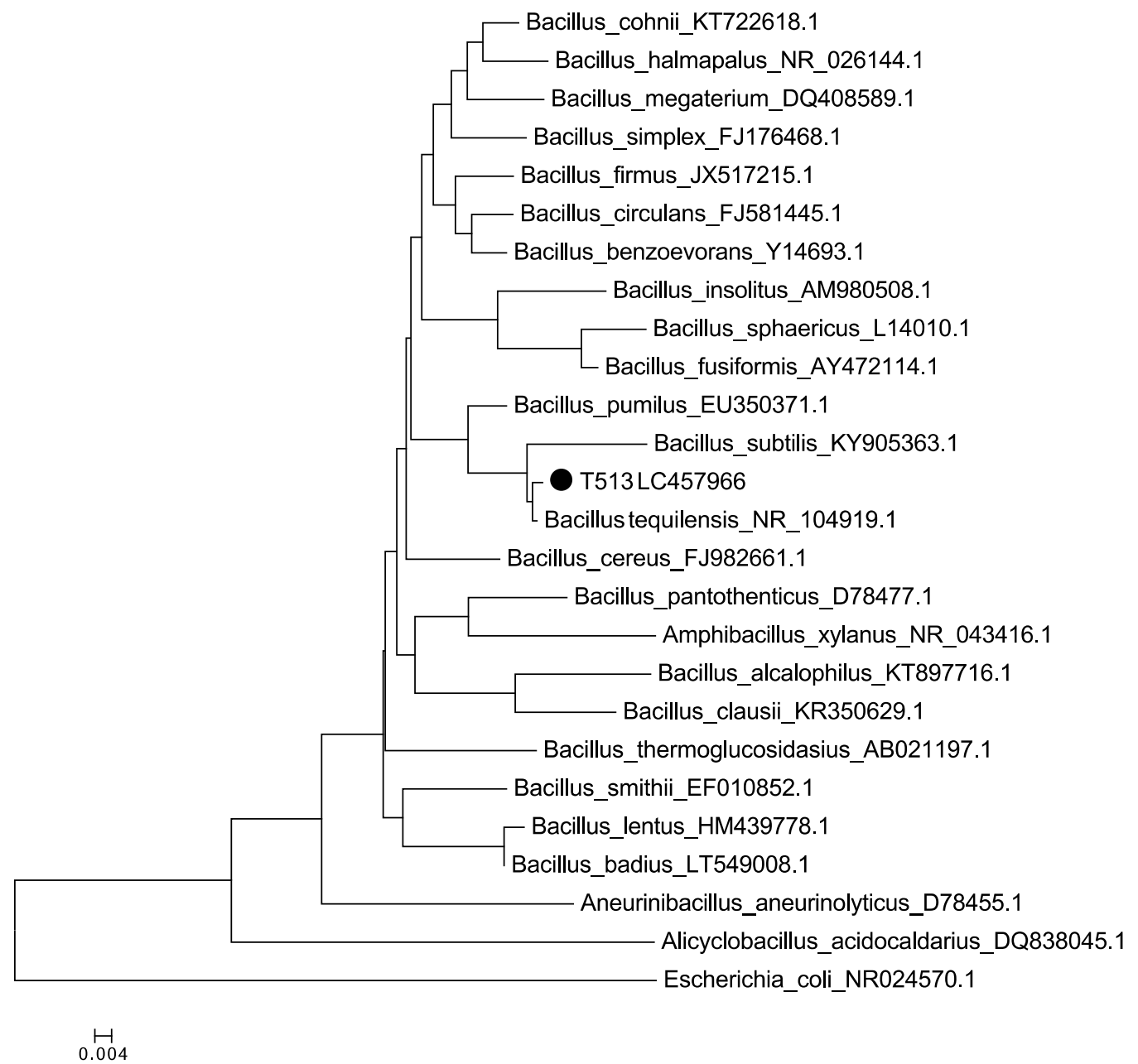

Figure 2. Neighbor-joining phylogenetic tree (bootstrap = 1000) constructed by MEGA7 showing the relationship of T513 with members of Bacillus present in GenBank based on 16S rRNA gene analysis 
Although Bacillus is known as industrial genus of bacteria due to their potential to produce various important enzyme, but rare of this genus reported as alginate lyase producer. When this report is written, there was no report about Bacillus tequilensis as Alginate lyase producer. The low similarity of T513's 16s rRNA gene sequence with those of in database identified as Bacillus species (95\%) indicating that $\mathrm{Alg} 07$ may be a novel Bacillus species. It showed possibility for T513 to be proposed as a new species as revealed by Drancourt et al. 2000 that the similarity level of $16 \mathrm{~S}$ rRNA gene for new taxa at genus and species level are below of $97 \%$ and $99 \%$, respectively.

\section{Optimum temperature and thermal stability}

Temperature range of $40-70^{\circ} \mathrm{C}$ was used to determine AlgT513 optimum temperature. The activity had been detected at a temperature of $40^{\circ} \mathrm{C}$, increasing at $45^{\circ} \mathrm{C}$ and although showing the highest activity at $50^{\circ} \mathrm{C}$, the activity was still detected up to the temperature of $70^{\circ} \mathrm{C}$ (Figure 3 ). The activity of ALT513 retained about $50 \%$ after 105 minutes incubation at $50^{\circ} \mathrm{C}$ and still showed $100 \%$ activity after 180 minutes at $45^{\circ} \mathrm{C}$. Alginate lyase produced by Microbulbifer sp. 6532A also showed the highest activity at $50^{\circ} \mathrm{C}$ (Swift et al. 2014) as well as this produced by Pseudoalteromonas sp. SM0524 (Li et al. 2011). Some alginate lyases showed different optimum temperature such as those produced by Microbulbifer sp. ALW1 (Zhu et al. 2016) which had an optimum temperature of $45^{\circ} \mathrm{C}$. Others showed the optimum temperature at $40^{\circ} \mathrm{C}$ such as produced by marine Vibrio sp. NJ-04 (Zhu et al. 2018) and Marine Bacterium Bacillus sp. Alg07 (Chen et al. 2018). The higher optimum temperature of $55^{\circ} \mathrm{C}$ was showed by alginate lyase produced by Flavobacterium sp. Strain UMI01 (Inoue et al. 2014). Sphingomonas sp. ZH0 produced four alginate lyases, ZH0-I, ZH0-II, ZH0-III and $\mathrm{ZH} 0$-with a different optimum temperature of 42, 47, 52 and $37^{\circ} \mathrm{C}$ respectively (He et al. 2018).

\section{Optimum pH and its stability}

AlgT513 showed the highest activity in $0.05 \mathrm{M}$ Tris-Cl at $\mathrm{pH}$ of 8 among tested $\mathrm{pH}$ range of 5-9 (Figure 3) and tended to be more active at higher $\mathrm{pH}$ that showed by high activity at $\mathrm{pH}$ of 9 compared to $\mathrm{pH}$ of 4-6. AlgT513 also showed stability in all of tested $\mathrm{pH}$ (4-9) (Figure 4). Most of the alginate lyases were stable at a broad of $\mathrm{pH}$ range such as produced by Marine Vibrio sp. NJ-04 which exhibited maximum activity at $\mathrm{pH} 7.0$ and showed stability at broad $\mathrm{pH}$ range of $\mathrm{pH} 4.0$ to 10.0 (Zhu et al.2018). For instance, alginate lyase produced by Marine bacteria Wenyingzhuangia fucanilytica was active the most at $\mathrm{pH}$ 8.5 and stable at pH range from 5.5 to 9 (Pei et al. 2018). Microbulbifer sp. ALW1 has an optimum pH of 7.0 and stable over a broad pH range of 5.0-9.0 (Zhu et al. 2016). AlySJ-02 from Pseudoalteromonas sp. SM0524 exhibited its maximal activity at $\mathrm{pH} 8.0$ and retained its stability between $\mathrm{pH}$ 7.0-9.0 (Lee et al. 2011). The AlyIH from Isoptericola halotolerans CGMCC5336 showed the highest activity at pH 7.0 and was stable at pH 7.0-8.0 (Dou et al. 2013)

\section{Effect of metal ion}

Addition of $5 \mathrm{mM} \mathrm{CaCl}_{2}, \mathrm{MgCl}_{2}$ and $\mathrm{KCl}$ enhanced the activity of AlgT513 by 45, 26 dan 48\%. While $\mathrm{CoCl}_{2}$, $\mathrm{MnCl}_{2}$ and $\mathrm{ZnCl}_{2}$ repressed activity by 20,94 and $92 \%$ (Figure 5). Some Alginate Lyases showed the same reaction in the presence of $\mathrm{MgCl}_{2}, \mathrm{CaCl}_{2}$, and $\mathrm{KCl}$ such as those produced by Pseudoalteromonas sp. SM0524 (Li et al.2011), Microbulbifer sp. ALW1 (Zhu et al. 2016) and FlAlyA from Flavobacterium sp. Strain UMI-01 (Inoue et al.2014). Sphingomonas sp. ZH0 produced three alginate lyases where their activity strongly inhibited by $\mathrm{ZnCl}_{2}(\mathrm{He}$ et al. 2014) as well those produced by Microbulbifer sp. ALW1 (Zhu et al. 2016) Microbulbifer sp. 6532A (Swift et al. 2014) and Vibrio sp. NJ-04 (Zhu et al. 2018).
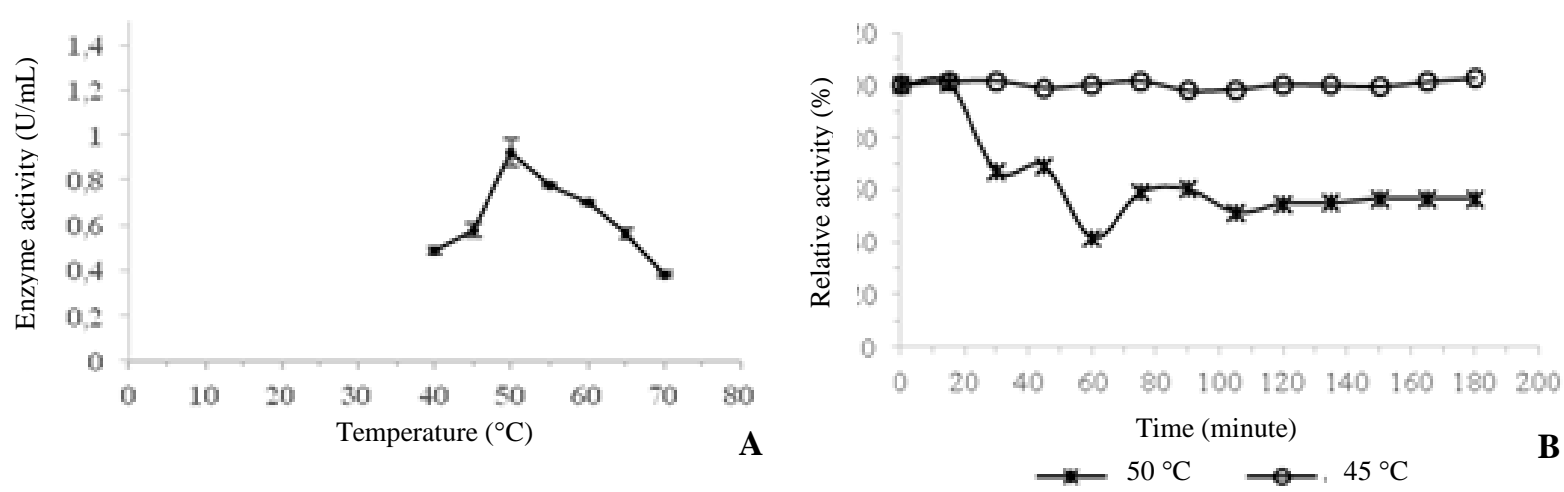

Figure 3. The activity of AlgT513 at various temperature (A) and its thermal stability (B) 

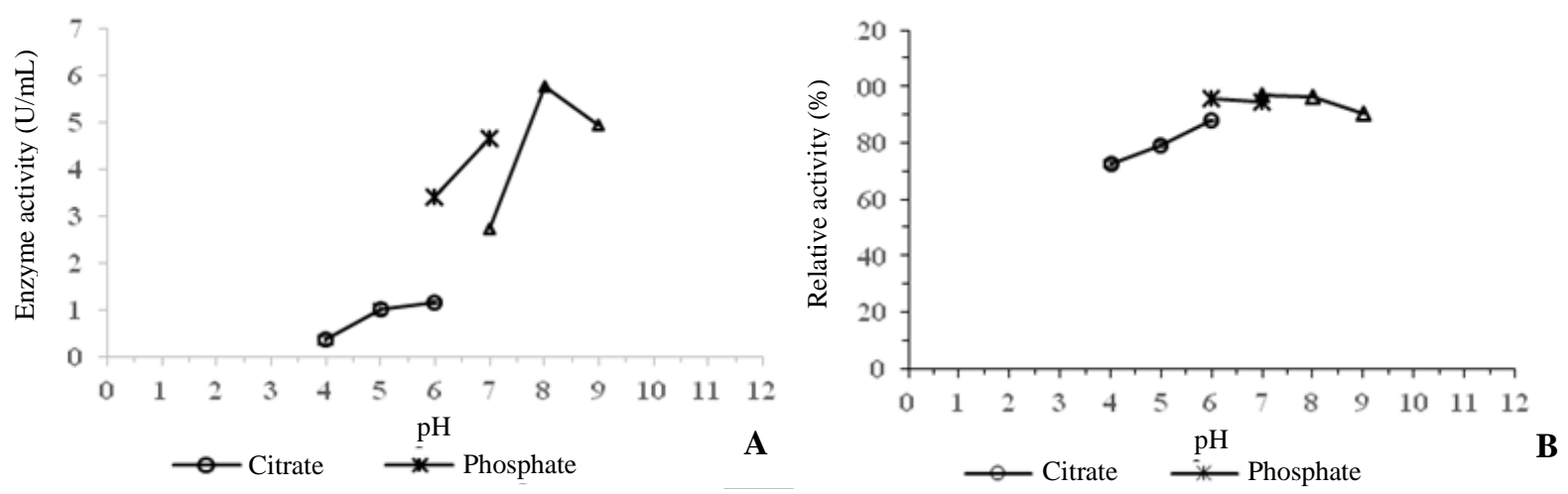

Figure 4. The activity of AlgT513 in various pH buffer (A) and its stability after $12 \mathrm{~h}$ incubation (B)

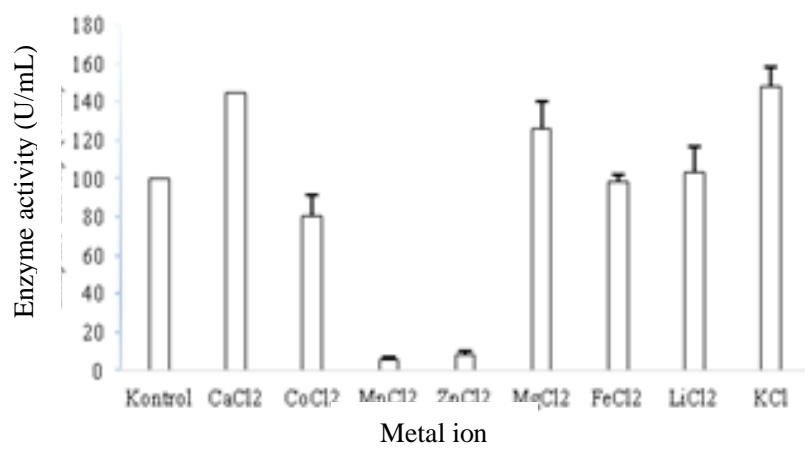

Figure 5. The activity of AlgT513 in the presence of $5 \mathrm{mM}$ metal ion

Table 1. The activity of AlgT513 in the presence of metal ion and detergent

\begin{tabular}{llrll}
\hline $\begin{array}{l}\text { Chemical/ } \\
\text { detergent }\end{array}$ & Concentration & \multicolumn{3}{c}{ Relative activity $(\%)$} \\
\hline None & $1 \mathrm{mM}$ & 100.00 & \pm & 13.58 \\
EDTA & $10 \mathrm{mM}$ & 10.62 & \pm & 1.66 \\
& $1 \mathrm{mM}$ & 8.64 & \pm & 2.54 \\
PMSF & $10 \mathrm{mM}$ & 106.35 & \pm & 0.89 \\
& $1 \mathrm{mM}$ & 30.83 & \pm & 10.18 \\
ME & $10 \mathrm{mM}$ & 95.36 & \pm & 6.18 \\
& $1 \%$ & 103.88 & \pm & 10.78 \\
Triton X100 & $0.1 \%$ & 120.53 & \pm & 2.81 \\
& $1 \%$ & 92.46 & \pm & 11.39 \\
SDS & $0.1 \%$ & 31.35 & \pm & 2.26 \\
& $1 \%$ & 90.51 & \pm & 13.75 \\
Tween 80 & $0.1 \%$ & 74.98 & \pm & 4.68 \\
& & 3.86 & \pm & 0.23 \\
\hline
\end{tabular}

\section{Effect of chemicals and detergent}

As showed in Table 1. the present of 1 and $10 \mathrm{mM}$ EDTA strongly inhibited AlgT513 activity as well as 10 mM PMSF. It showed that AlgT513 probably metalloserine enzyme. The activity of AlgT513 was not affected by the presence of ME and Triton-100. However, the addition of SDS and Tween 80 at 1 and $0.1 \%$ concentration

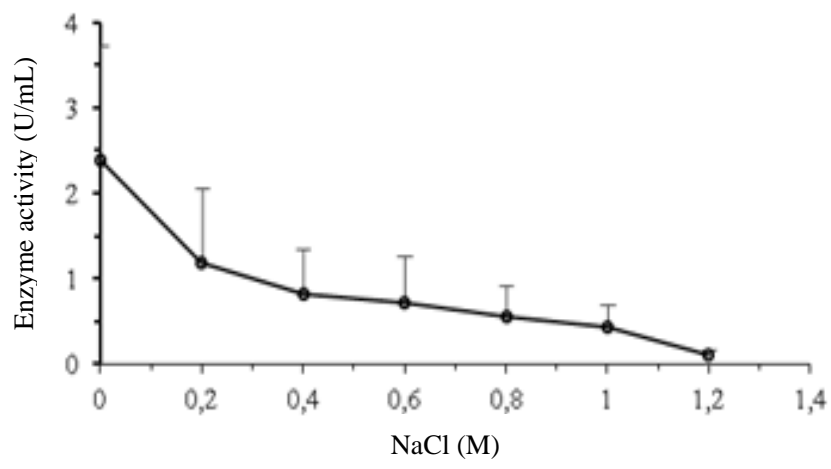

Figure 6. The activity of $\mathrm{AlgT} 513$ in the presence of $\mathrm{NaCl}$ at various concentration

respectively strongly inhibited AlgT513 activity (Table 1). As a comparison, Alginate lyase produced by Microbulbifer sp. ALW1 inhibited by the presence of EDTA but not by the presence of PMSF and ME (Zhu et al. 2014). Alginate lyase produced by Pseudoalteromonas sp. SM0524 also suggested as metalloalginate lyase which is showed by the inhibition of EDTA on its activity (Li et al. 2011).

$\mathrm{NaCl}$ showed inhibition effect on AlgT513 activity. Its activity got decreasing by the higher of $\mathrm{NaCl}$ concentration and showed no activity at the present $1.2 \mathrm{M} \mathrm{NaCl}$ (Figure 6). The presence of $\mathrm{NaCl}$ has been reported promoting the activity of most alginate lyases such as produced by Pseudoalteromonas sp. SM0524 (Li et al.2011), Microbulbifer sp. ALW1 (Zhu et al. 2016) Flavobacterium sp. Strain UMI-01 (Inoue et al. 2014), Bacillus sp. Alg07 (Chen et al.2018), S. degradans (Kim et al. 2012), Microbulbifer sp. 6532A (Swift et al. 2014), Vibrio sp. NJ04 (Zhu et al. 2018) and three alginate lyases produced by Sphingomonas sp. ZH0 (He et al. 2014). The concentration needed by each enzyme to reach maximum activity was different ranging of 0.2-1.2 M.

In conclusion, bacteria are known as source of valuable enzymes beneficial as degradation agent (Lee et al. 2012; Ethica and Sabdono 2017). In this study, Alginate lyase, an important biofilm degradation enzyme had been isolated from a bacterial novel strain T513 and successfully 
characterized. AlgT513 is suggested as a serine metalloenzyme due to inhibition of ethylenediaminetetraacetic acid (EDTA) and phenylmethylsulfonyl fluoride (PMSF). Inhibition of $\mathrm{NaCl}$ on AlgT513 makes it unique due to most of Alginate lyase activity produced by microorganisms enhancing by the presence of $\mathrm{NaCl}$. Further study to explore the application of ALgT513 on alginate degradation is needed to obtain the pattern of oligomers its produced and their bioactivity.

\section{ACKNOWLEDGMENTS}

The works were supported by national budget of Indonesia managed by Research Center for Marine and Fisheries Product Processing and Biotechnology, Agency of Marine and Fisheries Research and Human Resources, Marine and Fisheries Ministry.

\section{REFERENCES}

Agusman A, Danqing F. 2017. Fungal community structure of macroalga Ulva intestinalis revealed by miseq sequencing. Squalene Bull Mar Fisher Postharvest Biotechnol 12 (3): 99-106.

Agüero L, Zaldivar-Silva D, Pena L, Dias ML. 2017. Alginate microparticles as oral colon drug delivery device: A review. Carbohydr Polym 168: 32-43.

Altschul SF, Madden TL, Schäffer AA, Zhang J, Zhang Z, Miller W, Lipman DJ. 1997. Gapped BLAST and PSI-BLAST: a new generation of protein database search programs. Nucleic Acids Res 25 (17): 3387-3402

Bendtsen ST, Quinnell SP, Wei M. 2017. Development of a novel alginate-polyvinyl alcohol-hydroxyapatite hydrogel for 3D bioprinting bone tissue engineered scaffolds. J Biomed Mater Res Part A 105: 1457-1468.

Boyen C, Kloareg B, Polne-Fuller M, Gibor A. 1990. Preparation of alginate lyases from marine mollusks for protoplast isolation in brown algae. Phycologia 29: 173-181.

Cao L, Xie L, Xue X, Tan H, Liu Y, Zhou S. 2007. Purification and characterization of alginate lyase from Streptomyces species strain A5 isolated from banana rhizosphere. J Agric Food Chem 55: 5113-5117.

Chen P, Zhu Y, Men Y, Zeng Y, Sun Y. 2018. Purification and characterization of a novel alginate lyase from the marine bacterium Bacillus sp. Alg07. Mar Drugs 16: 86.

Chen Y, Dou W, Li H, Shi J, Xu Z. 2018. The alginate lyase from Isoptericola halotolerans CGMCC 5336 as a new tool for the production of alginate oligosaccharides with guluronic acid as reducing end. Carbohydr Res. DOI: 10.1016/j.carres.2018.06.005.

Ching SH, Bansal N, Bhandari B. 2017. Alginate gel particles-A review of production techniques and physical properties. Crit Rev Food Sci Nutr 57: 1133-1152.

Drancourt M, Bollet C, Carlioz A, Martelin R, Gayral JP, Raoult D. 2000. $16 \mathrm{~S}$ ribosomal DNA sequence analysis of a large collection of environmental and clinical unidentifiable bacterial isolates. J Clin Microbiol 38: 3623-30

Ethica SN, Sabdono A. 2017. Bio-Remediation Potential of Hydrolytic Bacteria Isolated from Hospital Liquid Biomedical Waste in Central Java. In Proceedings of the 3rd World Congress on New Technologies. DOI: 10.11159/icbb17.111. https: //avestia.com/NewTech2017_Proceedings/files/paper/ICBB/ICBB_11 1.pdf

Farrell EK, Tipton, PA. 2012. Functional characterization of AlgL, an alginate lyase from Pseudomonas aeruginosa. Biochemistry 51: 10259-10266.

Fujihara M, Nagumo T. 1992. The effect of the content of D-mannuronic acid and L-guluronic acid blocks in alginates on antitumor activity. Carbohydr Res 224: 343-47.
Guan J, Zhang Y, Liu Q, Zhang X, Chokshi R, Mao S. 2017. Exploration of alginates as potential stabilizers of nanosuspension. AAPS PharmSciTech. 18: 3172-3181.

He M, Guo M, Zhang X, Chen K, Yan J, Irbis C. 2018. Purification and characterization of alginate lyase from Sphingomonas sp. ZH0. J Biosci Bioeng xx: 1-7.

Heyraud A, Colin-Morel P, Girond S, Richard C, Kloareg B. 1996. HPLC analysis of saturated or unsaturated oligoguluronates and oligomannuronates. Application to the determination of the action pattern of Haliotis tuberculata alginate lyase. Carbohydr Res 291: 115-126.

Huang L, Zhou J, Li X, Peng Q, Lu H, Du Y. 2013. Characterization of new alginate lyase from newly isolated Flavobacterium sp. S20. J Ind Microbiol Biotechnol 40: 113-122.

Inoue A, Takadono K, Nishiyama R, Tajima K, Kobayashi T, Ojima T. 2014. Characterization of an alginate lyase, FlAlyA, from Flavobacterium sp. strain UMI-01 and its expression in Escherichia coli. Mar Drugs 12: 4693-4712.

Iwamoto Y, Araki R, Iriyama KI, Oda T, Fukuda H, Hayashida S, Muramatsu T. 2001. Purification and characterization of bifunctional alginate lyase from Alteromonas sp. strain no. 272 and its action on saturated oligomeric substrates. Biosci Biotechnol Biochem 65: 133142.

Kim DE, Lee EY, Kim HS. 2009. Cloning and characterization of alginate lyase from a marine bacterium Streptomyces sp. ALG-5. Mar Biotechnol 11: 10.

Kim HT, Chung JH, Wang D, Lee J, Woo HC, Choi IG, Kim KH. 2012. Depolymerization of alginate into a monomeric sugar acid using Alg17C, an exo-oligoalginate lyase cloned from Saccharophagus degradans 2-40. Appl Microbiol Biotechnol 93: 2233-2239.

Kobayashi T, Uchimura K, Miyazaki M, Nogi Y, Horikoshi K. 2009. A new high-alkaline alginate lyase from a deep-sea bacterium Agarivorans sp. Extremophiles 13: 121-129.

Lee SI, Choi SH, Lee EY, Kim HS. 2012. Molecular cloning, purification, and characterization of a novel polyMG-specific alginate lyase responsible for alginate MG block degradation in Stenotrophomas maltophilia KJ-2. Appl Microbiol Biotechnol 95: 1643-1653.

Li JW, Dong S, Song J, Li CB, Chen XL, Xie BB, Zhang YZ. 2011. Purification and characterization of bifunctional alginate lyase from Pseudoalteromonas sp. SM0524. Mar Drugs 9: 109-123.

Li L, Jiang X, Guan H, Wang P, Guo H. 2011. Three alginate lyases from marine bacterium Pseudomonas fluorescens HZJ216: purification and characterization. Appl Biochem Biotechnol 164: 305-317.

Lundqvist LC, Jam M, Barbeyron T, Czjzek M, Sandström C. 2012. Substrate specificity of the recombinant alginate lyase from the marine bacteria Pseudomonas alginovora. Carbohydr Res 352: 44-50.

Ma LY, Chi ZM, Li J, Wu LF. 2008. Overexpression of alginate lyase of Pseudoalteromonas elyakovii in Escherichia coli, purification, and characterization of the recombinant alginate lyase. World J Microbiol Biotechnol 24: 89-96.

Matsubara Y, Kawada R, Iwasaki KI, Oda T, Muramatsu T. 1998. Extracellular poly ( $\alpha$-L-guluronate) lyase from Corynebacterium sp.: purification, characteristics, and conformational properties. J Protein Chem 17: 29-36.

Miller, G. (1959). Determination of reducing sugar by DNS method. Anal. Chem 31: 426-428.

Moreno E, Cloeckaert A, Moriyón I. 2002. Brucella evolution and taxonomy. Vet Microbiol 90 (1-4): 209-227..

Mrsny R, Daugherty A, Short S, Widmer R, Siegel M, Keller GA. 1996. Distribution of DNA and alginate in purulent cystic fibrosis sputum: implications to pulmonary targeting strategies. J Drug Targeting 4: 233-243.

Müller M, Öztürk E, Arlov Ø, Gatenholm P, Zenobi-Wong M. 2017. Alginate sulfate-nanocellulose bioinks for cartilage bioprinting applications. Ann Biomed Eng 45: 210-223.

Murata K, Inose T, Hisano T, Abe S, Yonemoto Y, Yamashita T, Tagaki M, Sukaguchi K, Kimura A, Imanaka T. 1993. Bacterial alginate lyase: enzymology, genetics and application. J Ferment Bioeng 76: 427-437.

Nakazono S, Cho K, Isaka S, Abu R, Yokose T, Murata M, Ueno M, Tachibana K, Hirasaka K, Kim D, Oda T. 2016. Anti-obesity effects of enzymatically-digested alginate oligomer in mice model fed a high-fat-diet. Bioact Carbohydr Diet Fibre 7: 1-8.

Oakley JL, Pritchard MF, Powell LC, Forton JM, Doull I, Rye PD, Hill KE, Thomas DW. 2018. WS11. 1 Alginate oligomers as novel 
therapies to treat life-threatening pseudomonal multidrug-resistant bacterial infections. J Cyst Fibros 17: S19-S20.

Østgaard K. 1993. Determination of alginate composition by a simple enzymatic assay. Proc Fourteenth Int Seaweed Symp, 16-21 August 1992. Brest. Springer, Dordrecht. [France]

Østgaard K.1992. Enzymatic microassay for the determination and characterization of alginates. Carbohydr Polym 19: 51-59.

Park HH, Kam N, Lee EY, Kim HS. 2012. Cloning and characterization of a novel oligoalginate lyase from a newly isolated bacterium Sphingomonas sp. MJ-3. Mar Biotechnol 14: 189-202.

Pei X, Chang Y, Shen J. 2018. Cloning, expression and characterization of an endo-acting bifunctional alginate lyase of marine bacterium Wenyingzhuangia fucanilytica. Protein Expr Purif 154: 44-51.

Perullini M, Jobbágy M, Mouso N, Forchiassin F, Bilmes SA. 2010 Silica-alginate-fungi biocomposites for remediation of polluted water. J Mater Chem 20: 6479-6483.

Preston LA, Bender CL, Schiller NL 2001. Analysis and expression of algL, which encodes alginate lyase in Pseudomonas syringae pv. syringae. DNA sequence 12 (5-6), 455-461.

Pritchard MF, Powell LC, Khan S, Griffiths PC, Mansour OT, Schweins R, Beck K, Buurma NJ, Dempsey CE, Wright CJ, Hill KE, Thomas DW, Ferguson EL, Rye PD. 2017. The antimicrobial effects of the alginate oligomer OligoG $\mathrm{CF}-5 / 20$ are independent of direct bacterial cell membrane disruption. Sci Rep 7: 44731.

Rescignano N, Fortunati E, Armentano I, Hernandez R, Mijangos C, Pasquino R, Kenny JM. 2015. Use of alginate, chitosan and cellulose nanocrystals as emulsion stabilizers in the synthesis of biodegradable polymeric nanoparticles. J Colloid Interface Sci 445: 31-39.

Ryu M, Lee EY. 2011. Saccharification of alginate by using exolytic oligoalginate lyase from marine bacterium Sphingomonas sp. MJ-3. J Ind Eng Chem 17: 853-858.

Saitou N, Nei M. 1987. The neighbor-joining method: a new method for reconstructing phylogenetic trees. Mol Biol 4: 406-425.

Schaumann K, Weide G. 1995. Efficiency of uronic acid uptake in marine alginate-degrading fungi. Helgoländer Meeresuntersuchungen 49: 159.

Schütz K, Placht AM, Paul B, Brüggemeier S, Gelinsky M, Lode A. 2017. Three-dimensional plotting of a cell-laden alginate/methylcellulose blend: towards biofabrication of tissue engineering constructs with clinically relevant dimensions. J Tissue Eng Regen Med 11: 1574 1587.

Shimizu E, Ojima T, Nishita K. 2003. cDNA cloning of alginate lyase from abalone, Haliotis discus annai. Carbohydr Res 338: 2841-2852.

Steinert A, Weber M, DimmLmLer A, Julius C, Schütze N, Nöth U, Hendrich C. 2003. Chondrogenic differentiation of mesenchymal progenitor cells encapsulated in ultrahigh-viscosity alginate. J Orthop Res 21: 1090-1097.

Strand BL, Coron AE, Skjak-Braek G. 2017. Current and future perspectives on alginate encapsulated pancreatic islet. Stem Cells Translational Med 6: 1053-1058.

Suda K, Tanji Y, Hori K, Unno H. 1999. Evidence for a novel Chlorella virus-encoded alginate lyase. FEMS Microbiol Lett 180: 45-53.

Sun X, Shen W, Gao Y, Cai M, Zhou M, Zhang Y. 2019. Heterologous expression and purification of marine alginate lyase in Escherichia coli. Protein Expr Purif 153: 97-104.

Swift SM, Hudgens JW, Heselpoth RD, Bales PM, Nelson DC. 2014. Characterization of AlgMsp, an alginate lyase from Microbulbifer sp. 6532A. PloS one 9: e112939.

Tamura K, Stecher G, Peterson D, Filipski A, Kumar S. 2013. MEGA6: Molecular Evolutionary Genetics Analysis Version 6.0. Mol Biol Evol 30 (12): 2725-2729.

Vera J, Castro J, Gonzalez A, Moenne A. 2011. Seaweed polysaccharides and derived oligosaccharides stimulate defense responses and protection against pathogens in plants. Marine drugs, 9: 2514-2525.

Wang Y, Guo EW, Yu WG, Han F. 2013. Purification and characterization of new alginate lyase from a marine bacterium Vibrio sp. Biotechnol Lett35: 703-708.

Wijesekara I, Pangestuti R, Kim SK. 2011. Biological activities and potential health benefits of sulfated polysaccharides derived from marine algae. Carbohydr Polym 84: 14-21.

Yonemoto Y, Tanaka H, Yamashita T, Kitabatake N, Ishida Y, et al. 1993. Promotion of germination and shoot elongation of some plants by alginate oligomers prepared with bacterial alginate lyase. J Ferment Bioeng 75: 68-70

Zhao X, Xia Y, Li Q, Ma X, Quan F, Geng C, Han Z. 2014. Microwaveassisted synthesis of silver nanoparticles using sodium alginate and their antibacterial activity. Colloids and Surfaces A: Physicochem Eng Asp 444: 180-188.

Zhu B, Ni F, Ning L, Sun Y, Yao Z. 2018. Cloning and characterization of a new $\mathrm{pH}$-stable alginate lyase with high salt tolerance from marine Vibrio sp. NJ-04. Int J Biol Macromol 115: 1063-1070.

Zhu X, Li X, Shi H, Zhou J, Tan Z, Yuan M, Liu X. 2018 Characterization of a Novel Alginate Lyase from Marine Bacterium Vibrio furnissii H1. Mar Drugs 16: 30.

Zhu Y, Wu L, Chen Y, Ni H, Xiao A, Cai, H. 2016. Characterization of extracellular biofunctional alginate lyase from marine Microbulbifer sp. ALW1 and antioxidant activity of enzymatic hydrolysates. Microbiol Res 182: 49-58. 